\title{
Preparation and properties of open-cell zinc foams as human bone substitute material
}

\author{
Zhi-gang Li, Xiao-guang Zhang, Peng Huang, Lei Hu, and *Guo-yin Zu \\ College of Materials Science and Engineering, Northeastern University, Shenyang 110819, China
}

\begin{abstract}
Foamed zinc was prepared by infiltration casting process. The mechanical properties and corrosion resistance of the samples were studied, and the feasibility of the foamed zinc as a bone implant material was discussed. All the compression stress-strain curves of open-cell zinc foams with various cell size (1-4 mm) and porosity (55\%-67\%) show three stages: elastic stage, plastic stage, and densification stage. The compression strength increases with decreasing density. The smooth stress-strain response indicates a progressively deformation of open-cell zinc foam. In addition, the cell wall or edge bending and fracture are the dominated mechanisms for failure of open cell zinc foam. The immersion test for determining the corrosion rate of open cell zinc foam was conducted in simulated body fluid. It was found that zinc foam with a small cell size and high porosity showed a higher corrosion rate. In addition, open-cell zinc foams can effectively induce Ca-P deposition in immersion tests, showing good bioactivity. Therefore, the open cell zinc foam prepared in this experiment has a good potential application as a human bone substitute material.
\end{abstract}

Key words: open-cell zinc foams; vacuum infiltration casting; porosity; compressive properties; corrosion resistance CLC numbers: TG146.1 3 Document code: A Article ID: 1672-6421(2019 06-414-09

$\mathrm{M}$ edical metal materials have good mechanical properties and biocompatibility, and have been widely used as human hard tissue repair and replacement materials ${ }^{[1-3]}$. However, clinical studies have found that many medical metal materials do not match the elastic modulus of human bones, which will produce "stress shielding" phenomenon when implanted in the human body, resulting in loose or broken implants ${ }^{[4-6]}$. To solve the above problems, scholars have proposed a method of introducing pores into the medical metal materials ${ }^{[7,8]}$. The density, strength, and modulus of elasticity of porous metal materials can be adjusted by pore size and porosity, thus "stress shielding" can be alleviated or eliminated ${ }^{[9,10]}$. Porous structure and rough surface are conducive to the adhesion, proliferation, and differentiation of osteocytes, and promote the growth of new osteocytes into the pore ${ }^{[11,12]}$. Because the pore structure of foam metals is three-dimensionally connected, the body fluids and nutrients can be circulated, promoting tissue regeneration and reconstruction, and quickening the healing process ${ }^{[13,14]}$.

At present, titanium foam and tantalum foam are often used to replace bone tissue. It should be pointed

*Guo-yin Zu

Male, born in 1977, Ph.D., Professor. His research interests mainly focus on porous materials and metal composites.

E-mail: zugy@smm.neu.edu.cn

Received: 2019-08-21; Accepted: 2019-11-11 out that metal implants in human body, such as orthopedic steel plates and vascular stents, are usually not long-term; when the human body recovers, the implants need to be removed through surgery ${ }^{[15]}$. So, many researchers began to pay attention to metal materials that can be absorbed by the human body, such as magnesium, iron and their alloys ${ }^{[16]}$. But the degradation rate of magnesium alloys in the human body is too fast and uneven, which will lead to a rapid decline in mechanical properties, and generating a great amount of gases, resulting in a local increase in $\mathrm{pH}$ value ${ }^{[17,18]}$. The human body also can absorb zinc and zinc alloys. The chemical properties of zinc are more stable than magnesium but more active than iron. The degradation rate of zinc will not be too fast or too slow, so it is a better candidate for a medical biomaterial ${ }^{[19,20]}$. Besides, zinc is also one of the essential trace elements and plays a very important role in the human body ${ }^{[21]}$. So, zinc and zinc alloys are more suitable as scaffolds for bone tissue. However, there are few studies on foamed zinc as a human implant material.

In this study, the open-cell zinc foams were prepared to study the feasibility of foamed zinc as a bone implant material. Generally, foam alloys are prepared using the infiltration casting process. The traditional infiltration casting device usually has too many components, the pressure is difficult to control during the infiltration process, and the yield is low ${ }^{[22-24]}$. Therefore, a self- 
designed vacuum infiltration casting device was used. The pore structure, micromorphology, and porosity of the opencell zinc foams were characterized and measured. The quasistatic compression performances and corrosion resistance in the simulated body fluid (SBF) were analyzed and compared with human bone.

\section{Experimental procedure}

Commercially pure zinc ingot $(\geqslant 99.995 \%)$ and $\mathrm{CaCl}_{2}$ particles with four different sizes $(1.0,2.0,3.0,4.0 \mathrm{~mm})$ were used as raw materials. Table 1 shows the chemical composition of the zinc ingots. The open-cell zinc foams were prepared by vacuum infiltration casting process with the self-designed vacuum infiltration casting device, as shown in Fig. 1.

Table 1: Chemical composition of the zinc ingot (\%)

\begin{tabular}{cccccc}
\hline $\mathrm{Zn}$ & $\mathrm{Pb}$ & $\mathrm{Cd}$ & $\mathrm{Cu}$ & $\mathrm{Al}$ & $\mathrm{Sn}$ \\
\hline Bal. & 0.0016 & 0.001 & 0.0002 & 0.0003 & 0.0003 \\
\hline
\end{tabular}

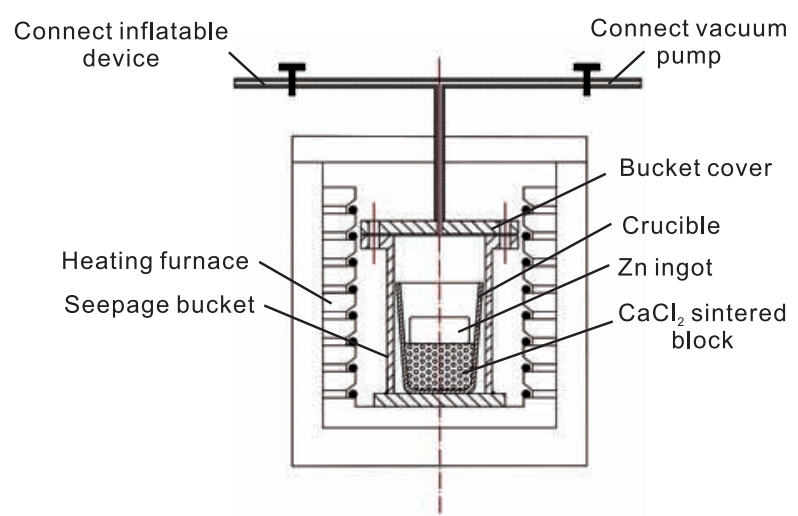

Fig. 1: Self-designed vacuum infiltration casting device

Figure 2 shows the procedures for fabricating open-cell zinc foams: (1) Sinter the spherical $\mathrm{CaCl}_{2}$ particles in the crucible at $650-700{ }^{\circ} \mathrm{C}$ for $5 \mathrm{~h}$ to prepare $\mathrm{CaCl}_{2}$ preform. (2) Put zinc ingot on the $\mathrm{CaCl}_{2}$ preform and heat in the vacuum infiltration device. At the same time, turn on the vacuum pump to maintain the internal vacuum of the device at $0.09-0.098 \mathrm{MPa}$. (3) Hold for $30 \mathrm{~min}$ at $570-620^{\circ} \mathrm{C}$. Then, open the pressure valve and adjust
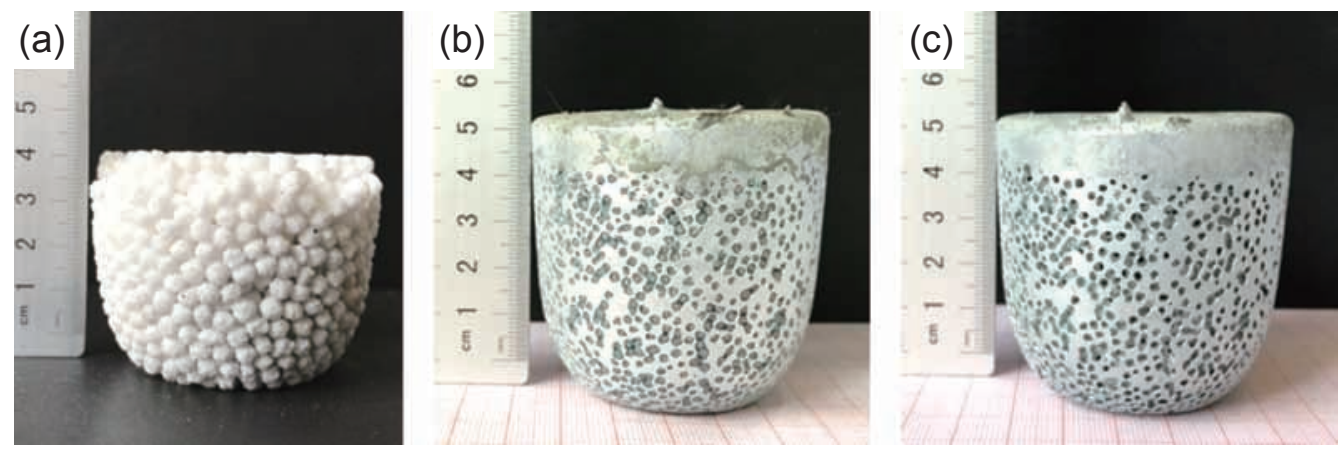

Fig. 2: (a) $\mathrm{CaCl}_{2}$ sintered block; (b) Compound of $\mathrm{Zn}$ and $\mathrm{CaCl}_{2}$; (c) Zinc foam

the seepage pressure to $0.3-0.7 \mathrm{MPa}$. (4) After cooling to room temperature, take out the crucible from the seepage bucket, a compound of foamed zinc and $\mathrm{CaCl}_{2}$ particles can be obtained. Put the compound in water to remove $\mathrm{CaCl}_{2}$ particles, then open-cell zinc foams were obtained.

A high definition digital camera was used to capture macroscopical photographs of open-cell zinc foams. The pore morphologies of open-cell zinc foams were observed by scanning electron microscopy (SEM, Ultra Plus, U $=15.0 \mathrm{kV}$, $\mathrm{SE})$. The quasi-static compression properties of open-cell zinc foams were tested by the AG-Xplus $100 \mathrm{kN}$ universal testing machine at room temperature, under a compression speed of 1 $\mathrm{mm} \cdot \mathrm{min}^{-1}$. Compressed samples are all cylinders of $\Phi 20 \mathrm{~mm} \times$ $20 \mathrm{~mm}$. After the compression test, the data was processed and analyzed according to GB/T31930-2015. The stress-strain curve, compressive strength, and Young's modulus of the samples were obtained.

In the in vitro immersion test of open-cell zinc foams, the electrolyte solution is SBF with $\mathrm{pH}$ value of 7.4. The configuration of SBF is shown in Table 2. The experiment was carried out according to ISO/FDIS23317. The size of the immersion samples is $\Phi 10 \mathrm{~mm} \times 3 \mathrm{~mm}$. The dosage of SBF is
$150 \mathrm{~mL} \cdot \mathrm{cm}^{-2}$, and the soaking temperature is $37{ }^{\circ} \mathrm{C}$. The SBF was replaced every 2 days, and the soaking time is $1 \mathrm{~d}, 4 \mathrm{~d}, 8$ $\mathrm{d}$, and $14 \mathrm{~d}$, respectively. Samples are weighted with analytical balance before immersion. After soaking, the samples were rinsed with water and dried by a dryer. The ULTRA PLUS field emission SEM with energy dispersive spectrometer was used to observe the surface after immersion. Then, $200 \mathrm{~g} \cdot \mathrm{L}^{-1}$ chromic acid solution was used to remove the corrosion products from the surface of the samples ${ }^{[25]}$. After cleaning, the cleaned sample was weighted with an analytical balance. The weightloss rates were calculated as follows:

$$
V=\frac{m_{0}-m_{\mathrm{t}}}{m_{0}} \times 100 \%
$$

where $m_{0}$ is the original mass of the sample $(\mathrm{g}), m_{\mathrm{t}}$ is the mass after cleaning $(\mathrm{g})$.

\section{Results and discussion}

\subsection{Pore structure characteristics}

Figure 3 shows the cross section of open-cell zinc foams prepared using $\mathrm{CaCl}_{2}$ particles with diameters of 1-4 mm. The 
Table 2: Addition order and quantity of reagents for $1 \mathrm{LSBF}$

$\begin{array}{ccccc}\text { Order } & \text { Reagent } & \text { Amount } & \text { Purity } & \text { Formula weight } \\ 1 & \mathrm{NaCl} & 8.035 \mathrm{~g} & 99.5 \% & 58.4430 \\ 2 & \mathrm{NaHCO}_{3} & 0.355 \mathrm{~g} & 99.5 \% & 84.0068 \\ 3 & \mathrm{KCl} & 0.225 \mathrm{~g} & 99.5 \% & 74.5515 \\ 4 & \mathrm{~K}_{2} \mathrm{HPO}_{4} \cdot 3 \mathrm{H}_{2} \mathrm{O} & 0.231 \mathrm{~g} & 99.0 \% & 228.2220 \\ 5 & \mathrm{MgCl}_{2} \cdot 6 \mathrm{H}_{2} \mathrm{O} & 0.311 \mathrm{~g} & 903.3034 \\ 6 & \mathrm{C}(\mathrm{HCl})=1 \mathrm{~mol}^{-1} & 39 \mathrm{~mL} & - & - \\ 7 & \mathrm{CaCl} & 0.292 \mathrm{~g} & 95.0 \% & 110.9848 \\ 8 & \mathrm{NaSO} & 99.0 \% & 142.0428 \\ 9 & \mathrm{Tris} & 0.072 \mathrm{~g} & 99.0 \% & 121.1356 \\ 10 & \mathrm{C}(\mathrm{HCl})=1 \mathrm{mo}^{-1} & 6.118 \mathrm{~g} & - & -\end{array}$
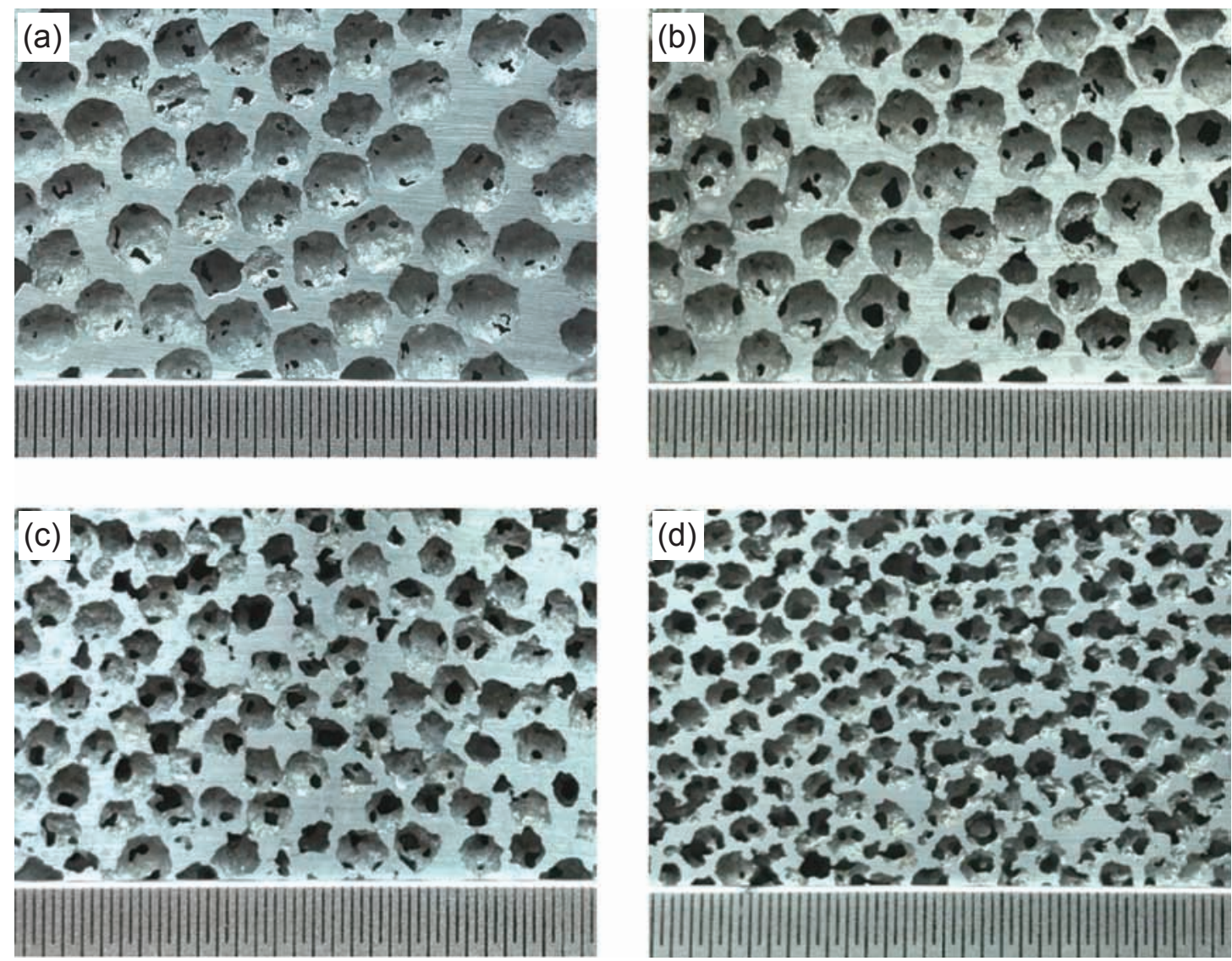

Fig. 3: Macroscopic morphologies of open-cell zinc foams with different pore sizes: (a) $4.0 \mathrm{~mm}$; (b) 3.0 $\mathrm{mm}$; (c) $2.0 \mathrm{~mm}$; (d) $1.0 \mathrm{~mm}$

pores of open cell zinc foams are spherical with the pore size equivalent to the size of $\mathrm{CaCl}_{2}$ particles. Therefore, the diameter of $\mathrm{CaCl}_{2}$ particles is regarded as the pore size of open-cell zinc foams.

As shown in Fig. 3, the overall structures of open-cell zinc foams with different pore sizes are neat with a uniform pore distribution. The shape of the hole was regular and spherical, and the greater the hole diameter, the better the integrality of the pore wall. The pores in the open-cell zinc foams are interconnected with each other, and the connectivity decreases with the increasing of pore size.

Figure 4 shows the microscopic appearance of open-cell zinc foams. It can be seen that the open-cell zinc foams characterize good pore connectivity with high porosity. The wall thickness between two cells becomes thinner with the increasing of the pore size, as marked by arrows in Fig. 4. There is a high matching degree between the pore structure and the human cancellous bone. The surface of the inner wall is rough, which 

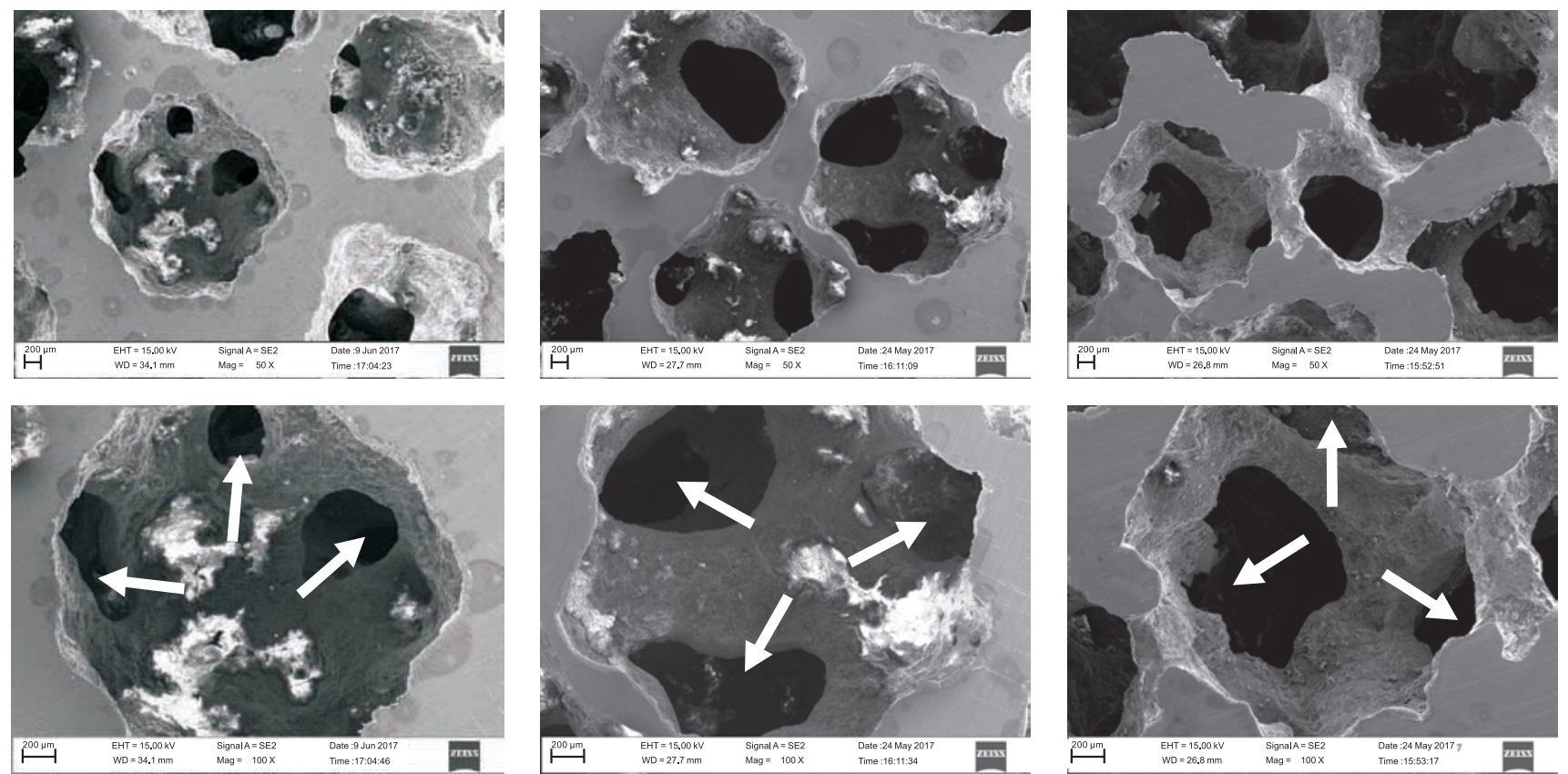

Fig. 4: SEM micrographs of open-cell zinc foams

is conducive to the attachment and growth of osteoblasts. At the same time, the pore structure of open-cell zinc foams is threedimensional. If implanted into the human body, these connected pores can promote the growth of new bone tissue in the pore, and make the implant form a strong bonding ability with the human skeleton. It also allows fluid and medications to be transported through the holes, which is beneficial to the growth of new bone tissue and accelerating the healing process.

\subsection{Compression performance}

Figure 5 shows the stress-strain curve of open-cell zinc foams. The average pore diameter is $1.0 \mathrm{~mm}$ and the porosity is $60 \%$. It can be seen that the stress-strain curve is smooth with nearly no obvious fluctuations. The deformation process of open cell zinc foam consists of three stages: (I) the elastic deformation stage, (II) the stress platform stage, and (III) the densification stage.

Figure 6 shows the macroscopic deformation of the opencell zinc foams at a strain range of 0 to $55 \%$. The three stages in the deformation of foam zinc during compression is more easily summarized by combining with the curve in Fig. 5 .

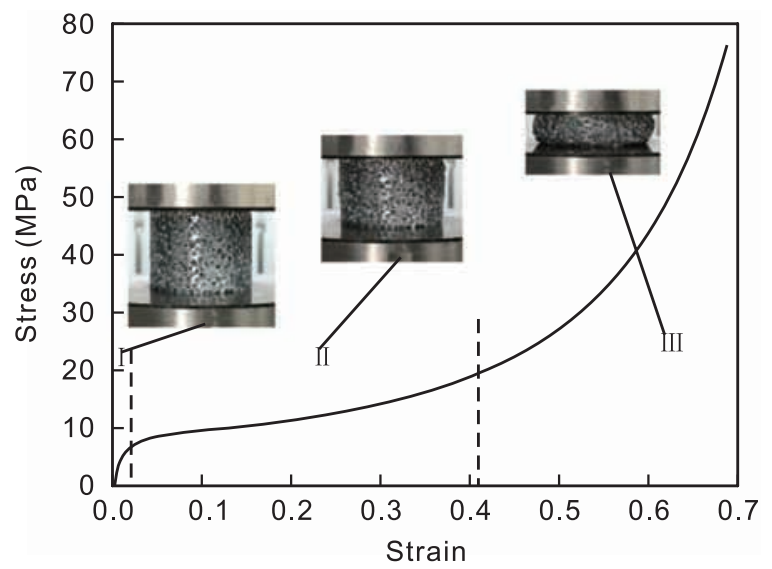

Fig. 5: Stress-strain curve of open-cell zinc foams with an average diameter of $1.0 \mathrm{~mm}$ and a porosity of $60 \%$
(1) Elastic deformation stage: The strain range of generally not more than 5\% is characteristic at this stage. As shown in Fig. 6, the obvious macro-deformation was not observed at a strain of $5 \%$. Bending deformation occurs at the place of cell edges and hole walls. The deformation occurring at this stage is reversible.

(2) Plastic deformation stage: The plastic deformation occurs when the strain exceeds the elastic limit. Deformation bands can be observed in the top side of sample. As the stress exceeds the yield stress of matrix, failure and fracture of cell edges took place at the areas where the cell wall is weakness and thus, local deformation zone formed (Fig. 6, $\varepsilon=10 \%$ ). With the increase of strain, the numbers of deformation bands increase, and the cell walls/edges are compacted. A rising hardening stage can be observed. The obvious increase of the sample diameter in the middle part with deformation indicates a higher Poisson's ratio than other foams, which usually shows a Poisson's ratio closing to zero.

(3) Densification stage: Most of the cells in the sample have been compacted (as shown in Fig. 6, $\varepsilon=45 \%$ ) in this stage. The friction and densification of compacted cells results in a sharp rise of compression stress. The diameter of the sample keeps increasing. Meanwhile, macro-cracks cannot be observed on the surface of the sample in this stage, indicating a progressive deformation mode of open cell zinc foam during compression.

Figure 7 shows the macrostructures of the failure modes at the locations of cell edge and hole walls. The failure Mode A is mainly caused by the tensile stress during the compression deformation. Mode B is due to the shear stress acting on the edge of the hole. The failure Mode $\mathrm{C}$ mainly occurs at the wall of the hole. During compression, the hole wall was bent and wrinkled under pressure. The tear was parallel to the compression direction at a weak place of the hole wall. In fact, in the deformation process of open cell zinc foam, the stress of each hole is very complicated due to its different structure, and its failure mode is usually superimposed on the above three failure modes. 


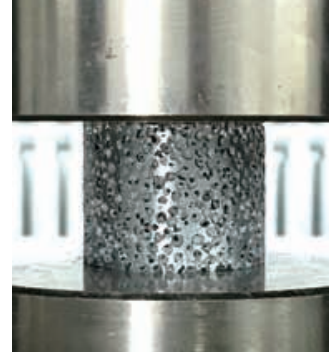

$\varepsilon=0$

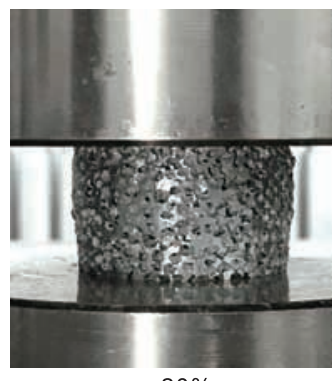

$\varepsilon=20 \%$

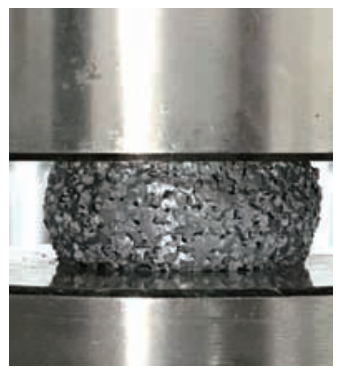

$\varepsilon=40 \%$

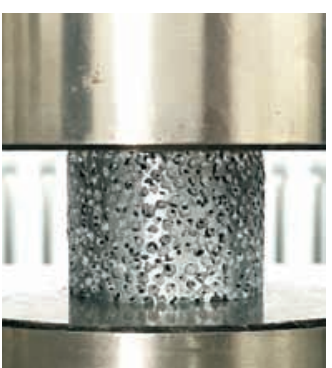

$\varepsilon=5 \%$

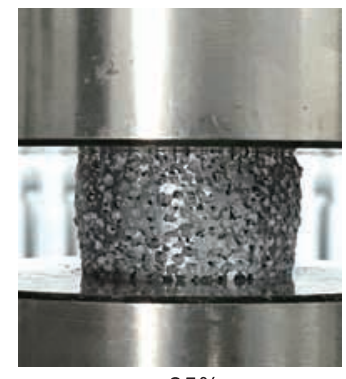

$\varepsilon=25 \%$

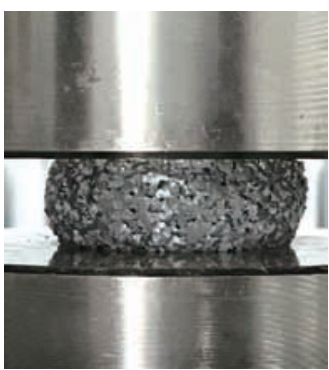

$\varepsilon=45 \%$

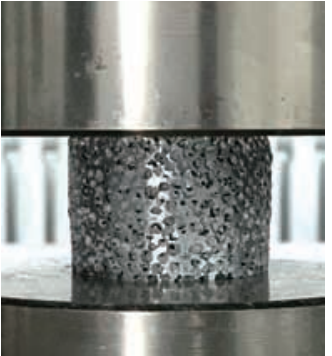
$\varepsilon=10 \%$

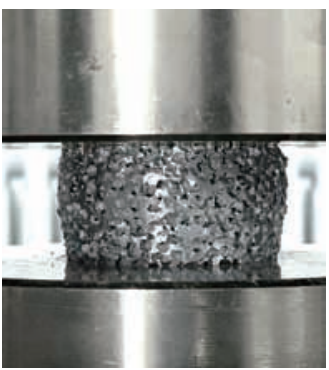

$\varepsilon=30 \%$

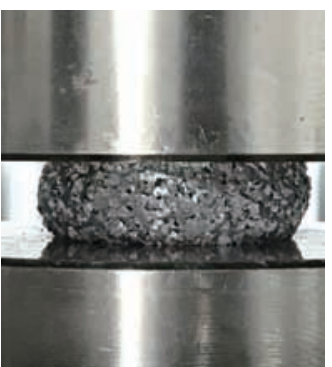

$\varepsilon=50 \%$

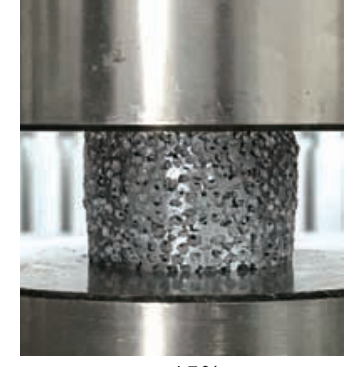
$\varepsilon=15 \%$

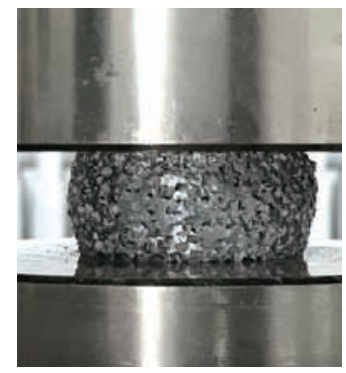

$\varepsilon=35 \%$

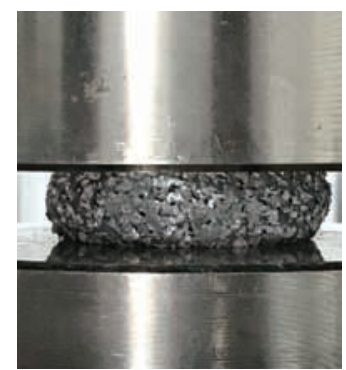

$\varepsilon=55 \%$

Fig. 6: Macroscopic deformation of open-cell zinc foams

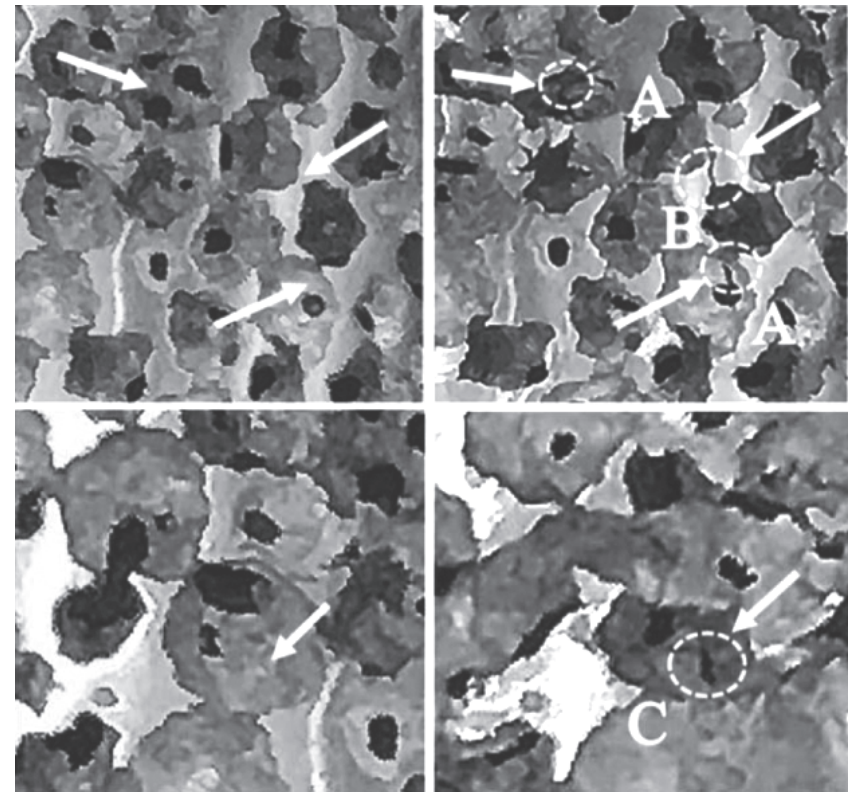

Fig. 7: Failure mode macroscopic views of hole wall/hole edge

According to the Gibson-Ashby model ${ }^{[26]}$, the relative density is proportional to the mechanical properties of porous materials. As the number of prisms on the same cross-sectional area becomes sparse with porosity increasing, the pressure resistance of the samples decreases. Figure 8 shows the stress-strain curves of open-cell zinc foams with different porosities. Combined with Table 3, the compressive strength, modulus of elasticity and platform stress of the samples decrease obviously with the increase of porosity. However, there is more compressible space for the sample to become denser before densification stage. In conclusion, porosity is an important factor affecting the mechanical properties of open-cell zinc foams.

Table 3 shows the mechanical properties of open-cell zinc foams: the porosity of the open-cell zinc foams with an average pore size of $1.0-1.5 \mathrm{~mm}$ is $55 \%-67 \%$, the elastic modulus is $0.6-1.35 \mathrm{GPa}$, and the compressive strength is 6.0-14.8 $\mathrm{MPa}$. The porosity of cancellous bone is $40 \%$ $90 \%$, the compressive strength is $2-10 \mathrm{MPa}$, and the elastic modulus is $0.1-2 \mathrm{GPa}^{[27]}$. The mechanical properties of opencell zinc foams are comparable to that of cancellous bone. When the compressive stress load is small, the open cell zinc foams undergo elastic deformation. Plastic deformation occurs when the load exceeds the limit of elastic deformation. In the plastic deformation stage, the deformation curve is relatively smooth, and the pore is gradually compacted during the deformation. Further plastic deformation leads to the fracture of the foamed zinc, which is similar to human bone. To sum up, the mechanical properties of open-cell zinc foams can meet the needs of implants. 

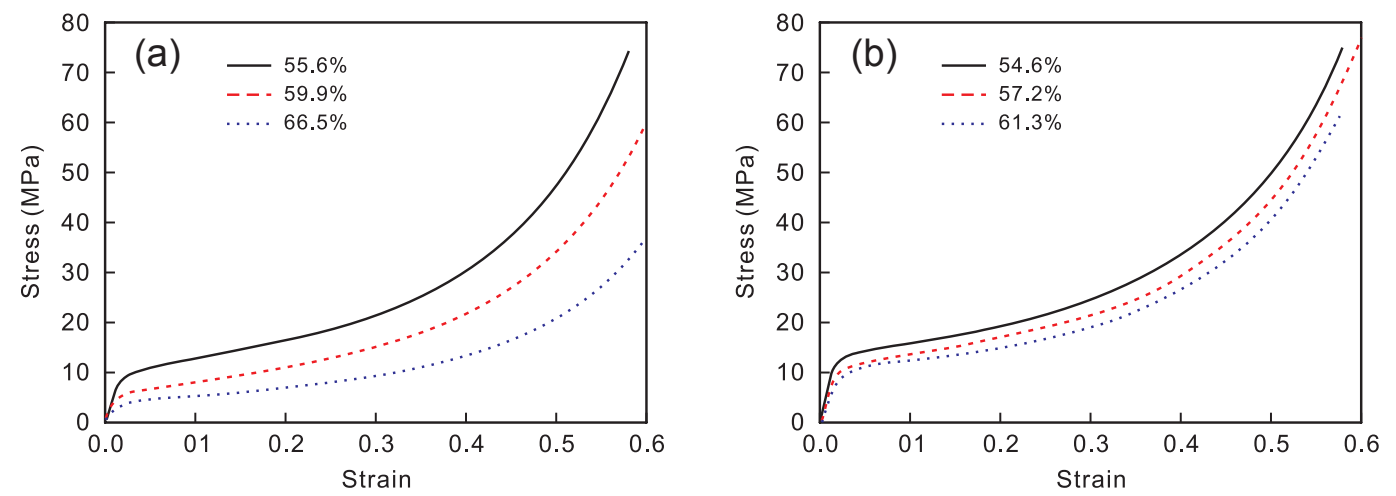

Fig. 8: Stress-strain curve of open-cell zinc foams with different porosities: (a) aperture is $1.0 \mathrm{~mm}$; (b) aperture is $1.5 \mathrm{~mm}$

Table 3: Mechanical properties of open-cell zinc foams

\begin{tabular}{ccccccc} 
Average pore size (Porosity) & $\mathbf{1 . 0}(\mathbf{5 5 . 6 \% )}$ & $\mathbf{1 . 0}(\mathbf{5 9 . 9 \% )}$ & $\mathbf{1 . 0}(\mathbf{6 6 . 5} \%)$ & $\mathbf{1 . 5}(\mathbf{5 4 . 6 \% )}$ & $\mathbf{1 . 5}(\mathbf{5 7 . 2} \%)$ & $\mathbf{1 . 5}(\mathbf{6 1 . 3} \%)$ \\
\hline Elastic modulus (GPa) & 1.21 & 1.03 & 0.59 & 1.35 & 1.17 & 0.92 \\
Compressive strength (MPa) & 13.13 & 9.65 & 6.03 & 14.82 & 11.53 & 9.62
\end{tabular}

\subsection{Corrosion behavior}

The $\mathrm{pH}$ values of the three groups of open-cell zinc foams are shown in Fig. 9. All the samples were immersed in the SBF for $350 \mathrm{~h}$. It can be seen that the $\mathrm{pH}$ value of these three groups increased slowly with prolonging the soaking time and tended to be stable when it reached about 7.62. The electrochemical corrosion mode of the samples in the SBF is mainly oxygen absorption corrosion. Specifically, Zn loses two electrons and becomes $\mathrm{Zn}^{2+}$ at anode, water and oxygen get electrons and turn into $\mathrm{OH}^{-}$at cathode. Between two electrodes, $\mathrm{Zn}^{2+}$ and $\mathrm{OH}^{-}$ bound together in solution to form $\mathrm{Zn}(\mathrm{OH})_{2}$. Thus, $\mathrm{pH}$ value of $\mathrm{SBF}$ increases slowly with the continuous formation of $\mathrm{OH}^{-}$as $\mathrm{Zn}$ dissolves in the solution. However, the maximum $\mathrm{pH}$ value of the three groups of SBF cannot always increase due to that the $\mathrm{OH}^{-}$is consumed in the solution to form insoluble $\mathrm{Zn}(\mathrm{OH})_{2}$ and $\mathrm{ZnO}$. Finally, the value of no more than 7.64 is gained during the whole immersion testing.

Figure 10 shows the SEM photographs of the surface morphology of three groups of open-cell zinc foams that soaked in SBF for different days. It can be seen that a small amount of

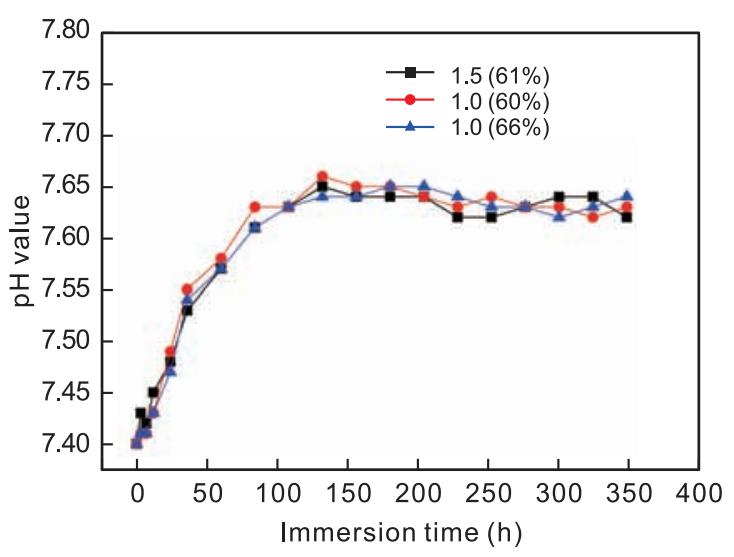

Fig. 9: Variations of $\mathrm{pH}$ value with immersion time in SBF spherical particulate corrosion products deposit dispersively on open-cell foamed zinc after 1 day of soaking. The number of spherical particles increases sharply after soaking for 4 days, and the surfaces of the samples are almost covered by particles. With the extension of soaking time, there is no obvious change in number, but the spheroidal particles gradually become larger. After more than 4 days of immersion, there are two forms of corrosion products formed on the surface. One is a solid reticular film formed on the surface of the sample, as marked by the red arrows in Fig. 10. The other is spherical particle formed on the solid reticular film, as marked by the blue arrows. After 14 days of soaking in the SBF, no obvious change occurred for corrosion products owing to the formation of passivation film on the surface of all the three groups of samples, as marked by yellow arrow.

After the immersing of three groups of open-cell zinc foams for 14 days, the corrosion products on the surface of the samples were analyzed by EDS. As shown in Fig. 11, the elements of $\mathrm{Ca}, \mathrm{P}, \mathrm{O}$, and $\mathrm{Zn}$ are detected on the spherical particles. Obviously, $\mathrm{Ca}$ and $\mathrm{P}$ come from the used SBF. The composition of corrosion products containing phosphate of $\mathrm{Zn}$, $\mathrm{Ca}$ and $\mathrm{Zn}(\mathrm{OH})_{2}$ can be inferred by combining the results of EDS and related references ${ }^{[28]}$.

Figure 12 shows the weight loss rate of the open-cell zinc foams samples after immersion in SBF for 14 days. The minimum weight loss rate of more than $4 \%$ is acquired, and it increases significantly with the increase of porosity. Owing to the larger surface area caused by higher porosity of opencell zinc foams, there is a higher probability for the sample and SBF to contact with each other and thus, the corrosion rate is accelerated. Generally, the surface area of open-cell zinc foams increases with the decrease of average pore size, which significantly accelerates the corrosion rate. However, the phenomenon of absence of the pore wall becomes serious, 


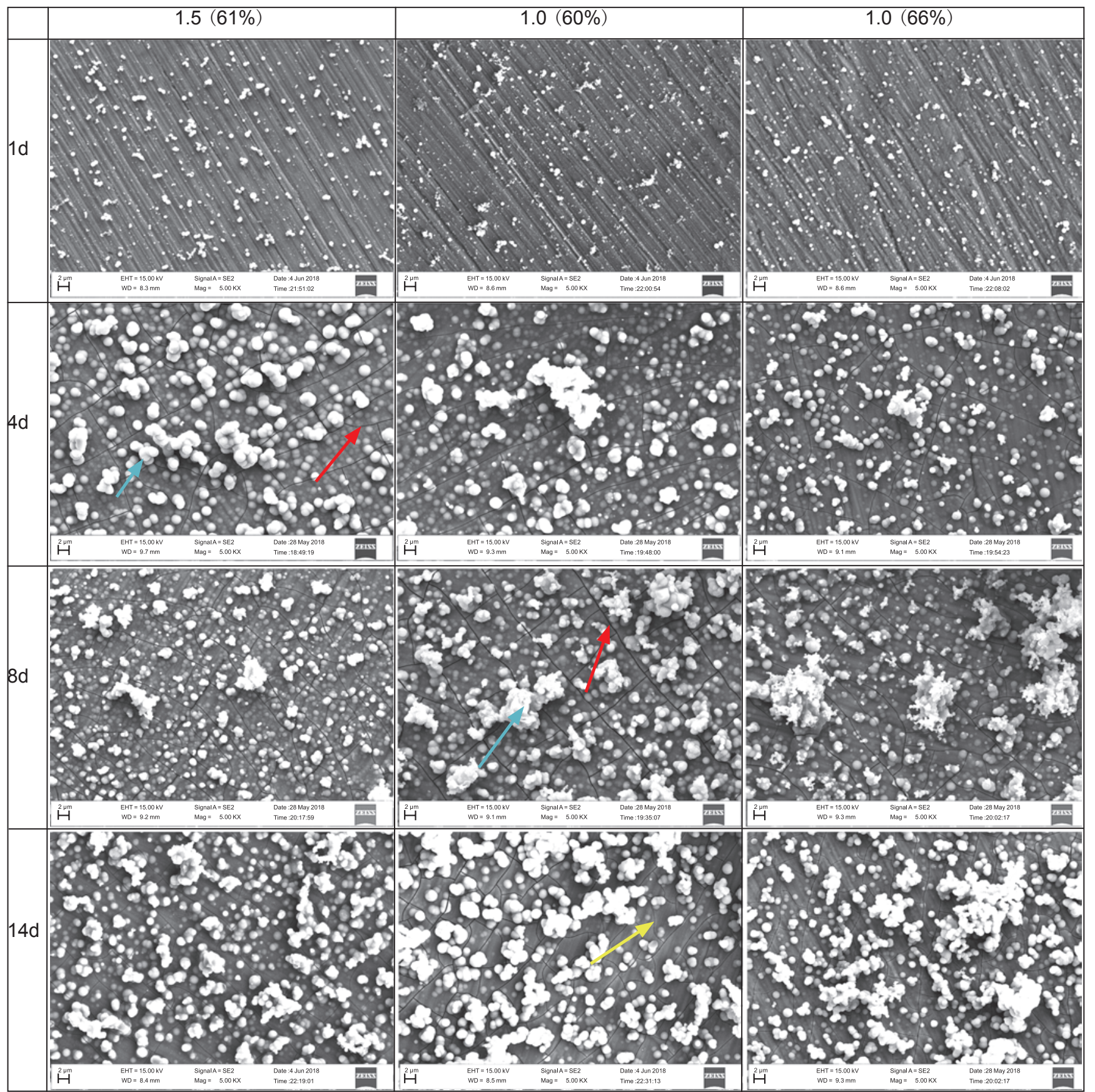

Fig. 10: Surface micrographs of open-cell zinc foams with different pore diameters and porosities after immersion in SBF for different days
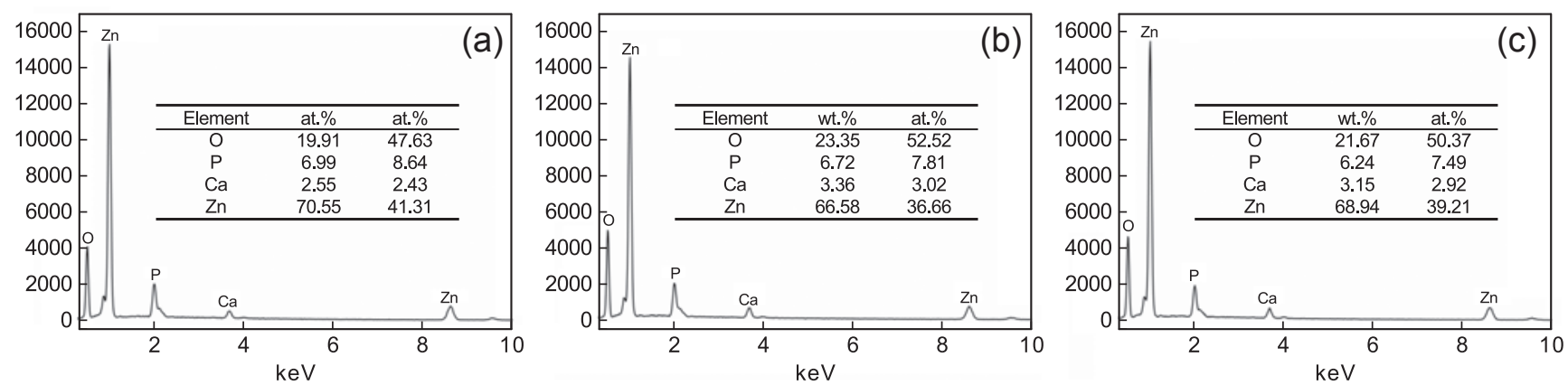

Fig. 11: EDS spectra of open-cell zinc foams after immersion in SBF for 14 days: (a) $1.5(61 \%)$; (b) $1.0(60 \%)$; (c) $1.0(66 \%)$ 


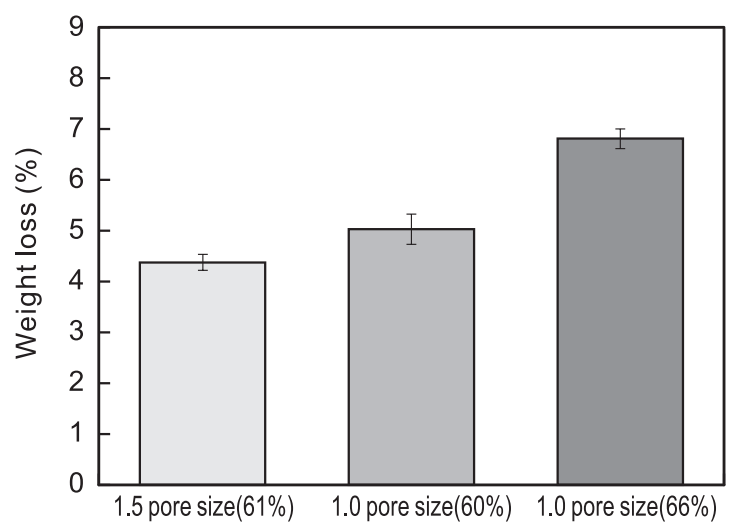

Fig. 12: Weight losses of open-cell zinc foams after immersion in SBF for 14 days

which reduces the contact area with the SBF. Thus, the corrosion rate just increases slightly. The sample with a porosity of $66 \%$ has the highest weight loss of $6.7 \%$. The corresponding average weight loss rate is about $2.5 \mathrm{mg} \cdot \mathrm{d}^{-1}$, which is significantly below the tolerance limit of $40 \mathrm{mg} \cdot \mathrm{d}^{-1}{ }^{[29]}$. This is mainly attributed to the network passivation film of solid-state on the surface of open-cell zinc foams, which significantly reduces its corrosion rate in SBF.

According to experimental results and analysis above, electrochemical corrosion occurs for the open-cell zinc foams in SBF. That is, foam zinc is gradually dissolved as anode in solution. The cathode reaction of zinc in neutral solution is oxygen adsorption reaction, in which $\mathrm{OH}^{-}$accumulated continuously, leading to the increase of $\mathrm{pH}$ value of solution. There is no hydrogen produced during the whole corrosion process. The reaction equations are as follows ${ }^{[30,31]}$ :

Anodic reaction:

$$
\mathrm{Zn} \rightarrow \mathrm{Zn}^{2+}+2 \mathrm{e}^{-}
$$

Cathodic reaction:

$$
2 \mathrm{H}_{2} \mathrm{O}+\mathrm{O}_{2}+4 \mathrm{e}^{-} \rightarrow 4 \mathrm{OH}^{-}
$$

$\mathrm{Zn}^{2+}$ and $\mathrm{OH}^{-}$combine to form water-insoluble $\mathrm{Zn}(\mathrm{OH})_{2}$

$$
2 \mathrm{Zn}+\mathrm{O}_{2}+2 \mathrm{H}_{2} \mathrm{O} \rightarrow 2 \mathrm{Zn}(\mathrm{OH})_{2}
$$

At the same time, $\mathrm{Cl}^{-}$in $\mathrm{SBF}$ reacts with $\mathrm{Zn}(\mathrm{OH})_{2}$ and precipitate of $\mathrm{Zn}(\mathrm{OH})_{2}$ is dissolved, destroying the dynamic equilibrium between the formation and dissolution of $\mathrm{Zn}(\mathrm{OH})_{2}$. Finally, $\mathrm{Zn}^{2+}$ reacts with $\mathrm{HPO}_{4}{ }^{2-}$ in solution to form waterinsoluble phosphate.

$$
\begin{gathered}
\mathrm{Zn}(\mathrm{OH})_{2}+2 \mathrm{Cl}^{-} \rightarrow \mathrm{Zn}^{2+}+2 \mathrm{OH}^{-}+2 \mathrm{Cl}^{-} \\
3 \mathrm{Zn}^{2+}+2 \mathrm{HPO}_{4}{ }^{2-}+2 \mathrm{OH}^{-}+2 \mathrm{H}_{2} \mathrm{O} \rightarrow \mathrm{Zn}_{3}\left(\mathrm{PO}_{4}\right)_{2}\left(\mathrm{H}_{2} \mathrm{O}\right)_{4}
\end{gathered}
$$

The deposition process of Ca-P in SBF is widely used to evaluate the biological activity of biomaterials, such as bioactive glass, surface-treated titanium, porous magnesium scaffolds, etc. ${ }^{[32-34]}$. As shown in Fig. 11, the corrosion products that were measured by EDS show that the elements of $\mathrm{Ca}, \mathrm{P}$, $\mathrm{O}$, and $\mathrm{Zn}$ exist on the spherical particles that precipitated on open-cell zinc foams. $\mathrm{ZnO}$ and $\mathrm{Zn}(\mathrm{OH})_{2}$ are common corrosion products of $\mathrm{Zn}$ in the solution with $\mathrm{Cl}^{-}$. With the extending of the immersion time for the samples in the SBF, $\mathrm{Zn}(\mathrm{OH})_{2}$ converts into $\mathrm{ZnO}$ which is more stable ${ }^{[35]}$. According to Eq. (3), hydroxide ions generate continuously with immersion time which increase the $\mathrm{pH}$ in solution. And thus, the elements of $\mathrm{Ca}$ and $\mathrm{P}$ prefer to precipitate on the surface of the cavity wall of open cell zinc foam, which is critical to the biological activity of the material. According to related research reports, the end of negatively charged ions can attract positive charged $\mathrm{Ca}^{2+}$ in SBF, and then adsorb $\mathrm{PO}_{4}{ }^{3-}$ in solution ${ }^{[36]}$. The $\mathrm{OH}^{-}$ accumulating on the surface of open-cell zinc foams can also act as similar role to the negative ion group in SBF. Once $\mathrm{Ca}^{2+}$ and $\mathrm{PO}_{4}{ }^{3-}$ are adsorbed onto the surface of open cell zinc foam, they react easily and combine with $\mathrm{SBF}$ to precipitate calcium phosphate because of the poor solubility of $\mathrm{Ca}^{2+}$ and $\mathrm{PO}_{4}{ }^{3-}$ in the solution even if the $\mathrm{pH}$ has reached $7.4^{[37]}$. Similarly, $\mathrm{Zn}^{2+}$ accumulated on the sample can also react with $\mathrm{PO}_{4}{ }^{3-}$ to form $\mathrm{Zn}_{3}\left(\mathrm{PO}_{4}\right)_{2}$. Finally, the corrosion product layer containing $\mathrm{ZnO}$, $\mathrm{Zn}(\mathrm{OH})_{2}$ and phosphate gradually precipitates on the opencell zinc foams. As a result, aggregated spherical granular corrosion products are formed.

\section{Conclusions}

Spherical $\mathrm{CaCl}_{2}$ particles were used as pre-formed sintered material, and open-cell zinc foams with different pore structures were successfully prepared by using a self-designed device through vacuum infiltration casting technology. The pore properties, compression properties, and corrosion behavior were studied. The main conclusions are as follows:

(1) The open-cell foamed zinc, whose porosity and pore structure match well with the cancellous bone of the human skeleton, can be prepared by using a self-designed device through vacuum infiltration casting technology.

(2) The elastic modulus and compressive strength of open-cell foamed zinc reduce with the increase of porosity. Meanwhile, the plastic deformation stage is prolonged with lower stress.

(3) The mechanical properties and compression deformation of the open-cell zinc foams match well with the cancellous bone. By adjusting the porosity of open-cell zinc foams, the elastic modulus can be adjusted appropriately to match the elastic modulus of the human bone in the human body. It is a promising bone tissue engineering material for implanting into the human body.

(4) SBF soaking experiments show that open-cell foamed zinc has good corrosion resistance in SBF. Although the corrosion resistance of open-cell zinc foams decreases with increasing porosity, the average daily average of dissolved $\mathrm{Zn}$ of open-cell zinc foams with a porosity of $66 \%$ is still far below the endurance limit of the human body. In addition, the phenomenon of Ca-P deposition in zinc foams is induced during the immersion test, which shows good biological activity.

\section{References}

[1] Zhang Y T, Liu H Y, Wang C, et al. Development trend and research application: Situation of biomedical materials. Hot Processing Technology, 2017, 46 (4): 21-26. (In Chinese) 
[2] Ren Y B, Yang K, Liang Y. Research and Development of New Biomedical Metallic Materials. Materials Reports, 2002, 2: 1215. (In Chinese)

[3] Geetha M, Singh A K, Asokamani R, et al. Ti based biomaterials, the ultimate choice for orthopaedic implants - A review. Progress in Materials Science, 2009, 54(3): 397-425.

[4] Nagels J, Mariëlle S, Rozing P M. Stress shielding and bone resorption in shoulder arthroplasty. J Shoulder Elbow Surg, 2003, 12(1): 35-39.

[5] Chen J, Ma F, Liu P, et al. Effects of different processing conditions on super-elasticity and low modulus properties of metastable $\beta$-type Ti-35Nb-2Ta-3Zr alloy. Vacuum, 2017, 146: 164-169.

[6] Engh C A, Young A M, Engh C A, et al. Clinical consequences of stress shielding after porous-coated total hip arthroplasty. Clinical Orthopaedics \& Related Research, 2003, 417: 157-163.

[7] Wang X, Xu S, Zhou S, et al. Topological design and additive manufacturing of porous metals for bone scaffolds and orthopaedic implants: A review. Biomaterials, 2016, 83: 127141.

[8] Arabnejad S, Johnston R B, Pura J A, et al. High-strength porous biomaterials for bone replacement: A strategy to assess the interplay between cell morphology, mechanical properties, bone ingrowth and manufacturing constraints. Acta Biomaterialia, 2016, 30(8): 345-356

[9] Torres $\mathrm{Y}$, Trueba P, Pavón J, et al. Designing, processing and characterisation of titanium cylinders with graded porosity: An alternative to stress-shielding solutions. Materials \& Design, 2014, 63(2): 316-324.

[10] Arabnejad S, Johnston B, Tanzer M, et al. Fully porous 3D printed titanium femoral stem to reduce stress-shielding following total hip arthroplasty. Journal of Orthopaedic Research, 2017, 35(8): 1774-1783.

[11] Min S X, Jin A M. Studies on biomedical materials-bone interface. International Journal of Biomedical Engineering, 2000, 23(6): 353-358. (In Chinese)

[12] Anselme K. Osteoblast adhesion on biomaterials. Biomaterials, 2000, 21(7): 667-681

[13] Wu S, Liu X, Yeung K, et al. Biomimetic porous scaffolds for bone tissue engineering. Materials Science \& Engineering R, 2014, 80(1): 1-36.

[14] Zhang Z, Jones D, Yue S, et al. Hierarchical tailoring of strut architecture to control permeability of additive manufactured titanium implants. Materials Science \& Engineering C Materials for Biological Applications, 2013, 33(7): 4055-4062.

[15] Tao H R, Jiang Y. Research progress of degradable magnesium alloy materials for internal fixation. International Journal of Orthopaedics, 2008, 29(5): 293-294. (In Chinese)

[16] Zheng Y F, Liu B, Gu X N. Research Progress in Biodegradable Metallic Materials for Medical Application. Materials Review, 2009, 23(1): 1-6. (In Chinese)

[17] Zhang S, Zhang X, Zhao C, et al. Research on an Mg-Zn alloy as a degradable biomaterial. Acta Biomaterialia, 2010, 6(2): 626-640.

[18] Song G. Control of biodegradation of biocompatable magnesium alloys. Corrosion Science, 2007, 49(4): 1696-1701.

[19] Mostaed E, Sikorajasinska M, Mostaed A, et al. Novel Zn-based alloys for biodegradable stent applications: Design, development and in vitro degradation. Journal of the Mechanical Behavior of Biomedical Materials, 2016, 60: 581-602.
[20] Chen Y, Zhang W, Maitz M F, et al. Comparative corrosion behavior of $\mathrm{Zn}$ with $\mathrm{Fe}$ and $\mathrm{Mg}$ in the course of immersion degradation in phosphate buffered saline. Corrosion Science, 2016, 111: 541-555.

[21] Hambidge K M, Krebs N F, Miller L V. Zinc: Physiology and Health Effects. Encyclopedia of Food \& Health, 2016: 633-637.

[22] Zhou X Y, Shang B W, Liu H Z. Preparation of open cell foam aluminum with negative pressure infiltration method and its defect analysis. Shanxi Chemical Industry, 2008, 28(4): 1-5. (In Chinese)

[23] Wu J G, Wang L C, Wang F. Study on the suction infiltration process of the composite aluminium foam. Foundry Equipment and Technology, 2011(2): 6-9. (In Chinese)

[24] Huo D W, Yang J, Zhou X Y, et al. Preparation of opencelled aluminum foams by counter-gravity infiltration casting. Transactions of Nonferrous Metals Society of China, 2012, 22(1): 85-89.

[25] Vojtěch D, Kubásek J, Serák J, et al. Mechanical and corrosion properties of newly developed biodegradable Zn-based alloys for bone fixation. Acta Biomaterialia, 2011, 7(9): 3515-3522.

[26] Gibson L J, Ashby M F. Cellular solids: structure and properties. Cambridge: Cambridge University Press, 1997: 247-259.

[27] Wu S, Liu X, Yeung K W K, et al. Biomimetic porous scaffolds for bone tissue engineering. Materials Science \& Engineering $\mathrm{R}$, 2014, 80(1): 1-36.

[28] Vojtěch D, Kubásek J, Šerák J, et al. Mechanical and corrosion properties of newly developed biodegradable $\mathrm{Zn}$-based alloys for bone fixation. Acta Biomaterialia, 2011, 7(9): 3515-3522.

[29] Fosmire G J. Zinc toxicity. American Journal of Clinical Nutrition, 1990, 51(2): 225-227.

[30] Chen Y, Zhang W, Maitz M F, et al. Comparative corrosion behavior of $\mathrm{Zn}$ with $\mathrm{Fe}$ and $\mathrm{Mg}$ in the course of immersion degradation in phosphate buffered saline. Corrosion Science, 2016, 111: 541-555.

[31] Liu X, Sun J, Qiu K, et al. Effects of alloying elements (Ca and $\mathrm{Sr}$ ) on microstructure, mechanical property and invitro, corrosion behavior of biodegradable $\mathrm{Zn}-1.5 \mathrm{Mg}$ alloy. Journal of Alloys \& Compounds, 2016, 664: 444-452.

[32] Lu X, Leng Y. Theoretical analysis of calcium phosphate precipitation in simulated body fluid. Biomaterials, 2005, 26(10): 1097-1108.

[33] Toworfe G K, Composto R J, Shapiro I M, et al. Nucleation and growth of calcium phosphate on amine-, carboxyl- and hydroxylsilane self-assembled monolayers. Biomaterials, 2006, 27(4): 631-642.

[34] Yazdimamaghani M, Razavi M, Vashaee D, et al. Surface modification of biodegradable porous Mg bone scaffold using polycaprolactone/bioactive glass composite. Materials Science and Engineering: C, 2015, 49(4): 436-444.

[35] Winiarski J, Tylus W, Szczygiel B. EIS and XPS investigations on the corrosion mechanism of ternary Zn-Co-Mo alloy coatings in $\mathrm{NaCl}$ solution. Applied Surface Science, 2016, 364: 455-466.

[36] Das K, Bose S, Bandyopadhyay A. Surface Modifications and Cell-Materials Interactions with Anodized Ti. Acta Biomaterialia, 2007, 3(4): 573-585.

[37] Kuroda K, Ichino R, Okido M, et al. Hydroxyapatite coating on titanium by thermal substrate method in aqueous solution. Journa of Biomedical Materials Research, 2002, 59(2): 390-397.

This work was financially supported by the Key Research and Development Program of Liaoning Province (2019JH2/10100008), the Plan for Innovative Talents in Liaoning Higher Education Institutions (LR2018011), and the Plan for Young and Middle-aged Science and Technology Innovation Talent of Shenyang (RC170204). 